Article

\title{
Seismic Responses of a Cable-Stayed Bridge with Consideration of Uniform Temperature Load
}

\author{
Junjun Guo ${ }^{1}$, Jian Zhong ${ }^{2}$, Xinzhi Dang ${ }^{1}$ and Wancheng Yuan ${ }^{1, *}$ \\ 1 State Key Laboratory of Disaster Reduction in Civil Engineering, Tongji University, Shanghai 200092, China; \\ guojj@tongji.edu.cn (J.G.); leodangxz@163.com (X.D.) \\ 2 School of Civil and Hydraulic Engineering, Hefei University of Technology, Hefei 230009, China; \\ jzhong@hfut.edu.cn \\ * Correspondence: yuan@tongji.edu.cn; Tel.: +86-21-65982231
}

Academic Editor: Wen-Hsiang Hsieh

Received: 13 September 2016; Accepted: 29 November 2016; Published: 9 December 2016

\begin{abstract}
The effects of temperature load on the dynamic responses of cable-stayed bridges have attracted the attention of researchers in recent years. However, these investigations mainly focus on the influence of temperature on the dynamic characteristics of structures, such as vibration mode and frequency. This paper discusses the effects of uniform temperature changes on the seismic responses of a cable-stayed bridge. A three dimensional finite element model of a cable-stayed bridge using OpenSees is established for nonlinear time history analysis, and uniform temperature load is applied to the prototype bridge before the conducting of seismic excitation. Three ground motion records are selected from the PEER strong motion database based on the design spectrum. Case studies are then performed considering the varying temperature and the connections between the deck and pylons of the bridge. The result shows that the seismic responses of the bridge are significantly increased with the consideration of temperature load. Meanwhile, the types between the deck and pylon also have notable impacts on the seismic responses of the bridge with and without temperature changes. This research could provide a reference for designers during the design phase of cable-stayed brides.
\end{abstract}

Keywords: cable-stayed bridges; uniform temperature; earthquake; nonlinear analysis; deck to pylon connections

\section{Introduction}

In recent decades, cable-stayed bridges have been favored by bridge engineers due to their aesthetic configuration, fast and economical construction, and efficient utilization of materials. However, bridges of this type are susceptible to seismic excitation due to their low damping ratios and flexible components. Meanwhile, the effects of uniform temperature changes on the responses of cable-stayed bridges are significant due to their long spans. However, the concurrent of uniform temperature and earthquake loads are not considered in current design specifications. Therefore, it is necessary to investigate the seismic responses of cable-stayed bridges subjected to earthquake and uniform temperature.

The seismic behavior of cable-stayed bridges has been extensively investigated by many researchers in the past two decades. The impacts of near-fault ground motions [1,2] on the seismic responses of cable-stayed bridges were concerned by scholars, and different isolation devices [3-5] were designed to alleviate these influences. The nonlinear dynamic responses of cable-stayed bridges [6-8], including cable sag, geometry change of the whole bridge, soil-structure interaction, etc., were widely investigated due to the geometric and dynamic properties of these bridges. Passive control, as an effective seismic mitigation strategy, has been frequently used for seismic isolation of cable-stayed bridges in recent years $[4,9-13]$. The isolation systems can be approximately divided into four types: 
isolation bearings, cable restrainers, dampers, and innovative devices. The seismic isolation of these devices can be attributed to lengthening the fundamental period of structure or absorbing input seismic energy. For example, Donaneschi and Martinelli [14] adopted a passive control system consisting of hysteretic devices between the deck and piers of a cable-stayed bridge, and these devices not only dissipate the seismic energy introduced into the structure, but also shift the natural frequencies of the bridge far from the most dangerous input frequencies.

The effects of temperature on the vibration properties of long-span bridges have attracted the attention of researchers in recent years. These studies [15-17] mainly focus on the correlations between temperature and dynamic properties of these bridges, including frequency, mode shapes, and damping ratio. It is found that temperature is a critical source causing the variability of vibration properties of long-span bridges, and there is an overall decrease in modal frequency with the increase of temperature for these bridges. Some researchers [18,19] investigated the response of elastic cables with flexural-torsional stiffness and thermal effects, the result shows that the stresses within the boundary layers of cables will be significantly underestimated without consideration of flexural-torsional stiffness and thermal effects and their influence on the frequencies of cables. These effects will not only influence the dynamic behaviors of cables, but also the global dynamical response of whole bridge. This paper will mainly consider the impacts of thermal load on the seismic responses of a cable-stayed bridge. However, the concurrent of temperature and earthquake loads are usually not accounted in bridge design specifications. Some researchers have started to investigate the combination of these two loads. Qiu and Zhang [20] adopted Turkstra combination method to calculate the combination coefficient of temperature and earthquake loads, and the actions of these two loads are considered as stochastic variables with their own probabilistic distributions respectively. Shervin and Maghsoudi-Barmi [21] proposed a load combination that added uniform temperature load to the existing extreme event load combination. It is found that pylon reactions and deck axial forces are more vulnerable to concurrent loadings for cable-stayed bridges of longer spans.

Although previous researchers made some contributions to the combination of uniform temperature and earthquake loads, they regarded thermal load and seismic excitation as two separate actions. As a matter of fact, temperature action already exists in structure when an earthquake happens. Meanwhile, the seismic responses of these bridges are complicated, and some components may enter into nonlinear states during strong seismic excitation. It may not be reasonable to linearly add the two actions without considering the nonlinear properties of structures. Therefore, it is necessary to analyze the seismic responses of cable-stayed bridges based on the existing thermal load, and nonlinearity of bridge components should be considered in this process. A three-dimensional finite element model of the prototype bridge using OpenSees program is established. Then, three ground motion records based on the design response spectrum of the site of the prototype bridge are selected from the PEER Ground Motion Database. Nonlinear time history analysis of the prototype bridge with varying thermal loads and different deck to pylon connections are conducted to obtain the responses of the critical elements of the bridge. Finally, comparisons are made between the responses of the bridge with and without accounting for uniform temperature to evaluate the effects of the uniform temperature on the seismic responses of the bridge.

\section{Description of the Prototype Bridge}

The prototype bridge [22] has been chosen in this work based on an existing cable-stayed bridge in the northwest of China. The bridge has two symmetrical pylons, and a total span of $742 \mathrm{~m}$ with a main span of $430 \mathrm{~m}$ and a side span of $156 \mathrm{~m}$, as show in Figure 1a. The cables are arranged in two inclined planes with 68 cables in each plane. The semi-fan cable system was adopted due to its efficiency for long span cable-stayed bridges. A concrete deck and steel deck are respectively used in the side span and main span of the bridge, which will not only decrease the dead load of the main span, but also increase the dead load of the side span. Thus, the stiffness of the whole bridge will be enhanced. 
The modified A-shaped pylons of the bridge with total height of $150 \mathrm{~m}$ consist of an A-shaped component on the upper part and a wall in the lower part, as can be seen in Figure 1b. The hollow sections of the pylons are made up of concrete, which can save the costs of the pylons' erection and maintain the whole stiffness of the pylons at same time. The longitudinal deformation of the deck is assumed to be partly restrained at each pylon. That is to say, bearings are attached in the bridge to connect the deck and pylons. Therefore, the relative movement between the deck and the pylons will happen when the shear force in the longitudinal direction exceeds the yield force of bearings.

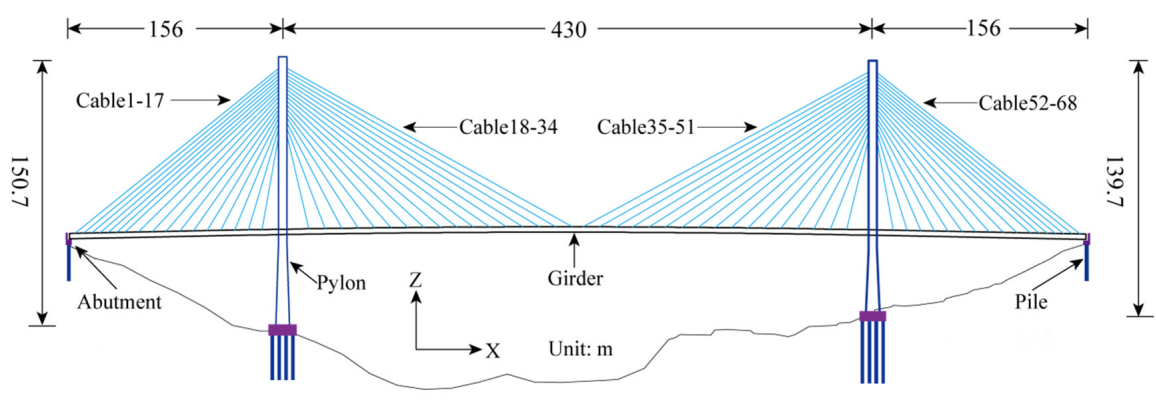

(a)
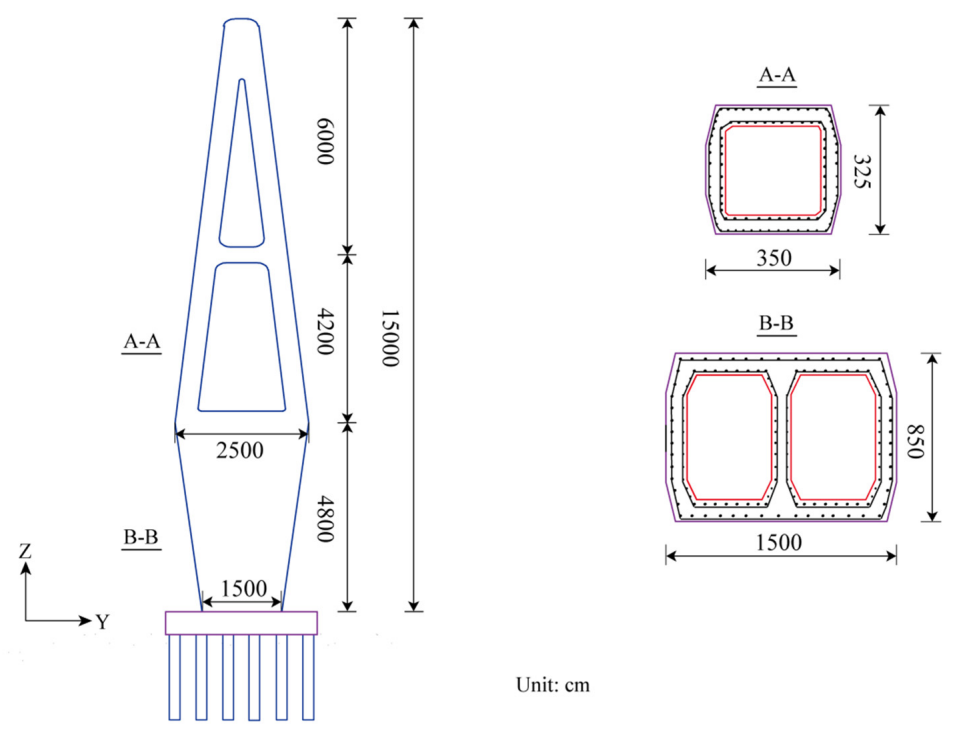

Unit: cm

(b)

Figure 1. General view of the prototype bridge: (a) longitudinal geometry of the bridge; (b) geometry of the bridge pylon.

\section{Finite Element Model}

The seismic analysis of the prototype bridge was performed using three dimensional (3D) finite element software OpenSees [23]. A total of 691 nodes and 532 elements were used in modeling the bridge. Figure 2 presents the 3D finite element modeling approaches of the components of the bridge and their property values. The pylons were modeled with fiber sections comprised of unconfined concrete, steel, and confined concrete. The deck was assumed to remain elastic during the whole stage, thus, linear-elastic beam-column elements were adopted according to Wilson and Gravelle [24]. In particular, the vertical, transversal, axial, and torsional stiffness properties (in Table 1) of the deck section are concentrated in a single central longitudinal spine, made up of 246 two-node beam elements. Additionally, 68 couples of transversal offset rigid links connect the spine nodes with each of the 136 cable anchorage points. The mass of each spine node is equally arranged at its anchorage points, so 
that the longitudinal rotational inertia of the deck can be considered in the model [25]. Several methods have been proposed to model the stay cables, such as the single truss model (one element cable system-OECS) [26] and multi-element cable system (MECS) [25,27-29]. The OECS model does not account for the local cable transversal motion, and fails to describe its interaction with the global dynamics. On the contrary, the MECS model can capture the local vibration of stay cables, thus, it is considered a more refined cable modeling method. However, the less refined OECS model is adopted in this paper due to its simplicity and less computational time. The stiffness characteristics of an inclined cable can exhibit nonlinear behavior due to cable tension and sag, and this effect was considered by linearization of the cable stiffness using an equivalent modulus of elasticity. The large-displacement truss element in OpenSees was used to simulate stay cables. The cable force can be applied to the bridge by defining a tension-only material with initial strain, and this initial strain can be calculated based on the force, equivalent modulus of elasticity, and the area of a cable. Rigid links were used to connect the cables to the pylons and deck. The passive pressure and the pile of the abutments were modeled with multilinear backbone curves recommended by Caltrans criteria [30]. Elasto-plastic bearings are used in the bridge, and the yield displacement and force are specified in Figure 2. Pounding between deck and abutments in the bridge is molded by zero-length elements using the bilinear model recommended by DesRoches et al. [31].

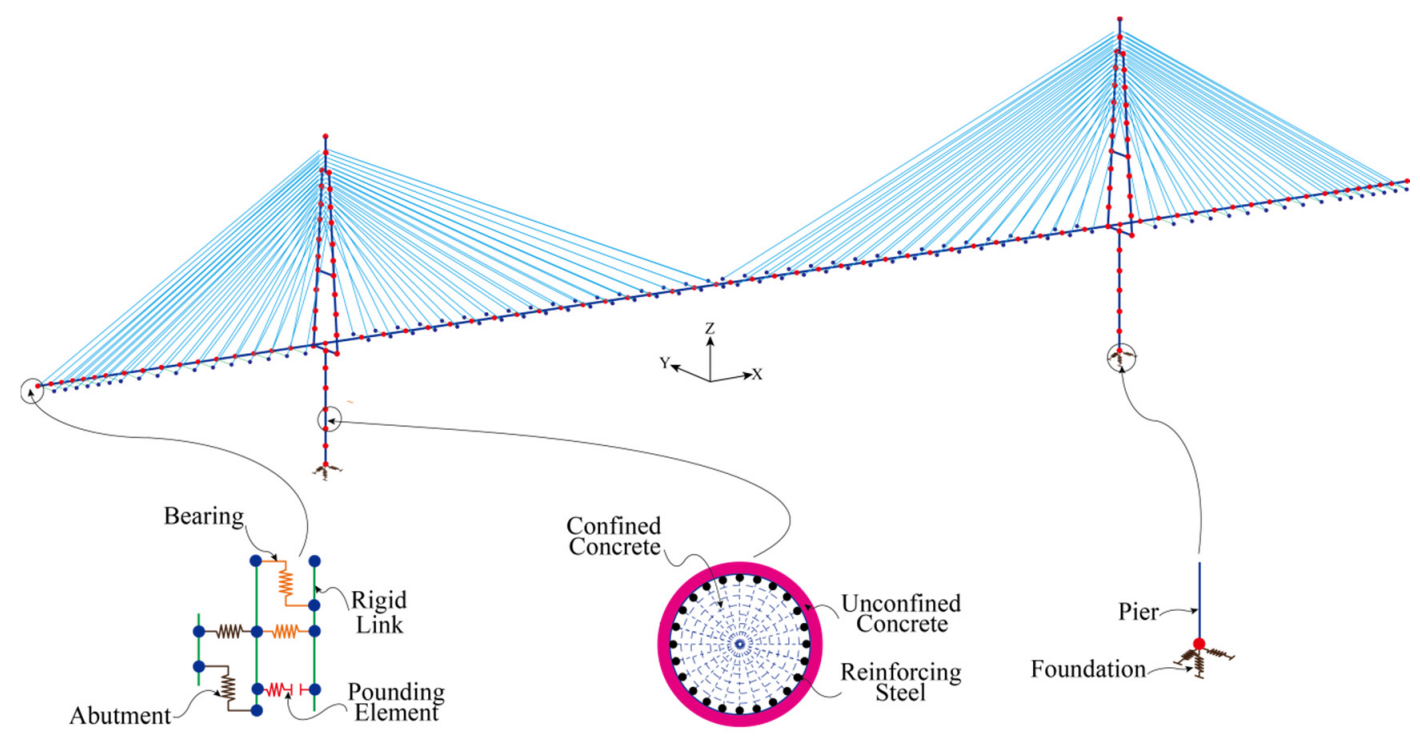

\begin{tabular}{|c|c|c|c|c|c|c|}
\hline 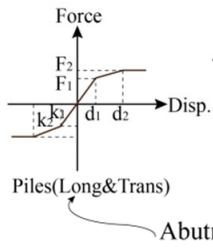 & 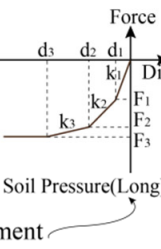 & 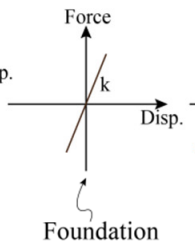 & $\sum_{\text {Bearing }}^{\mathrm{d}_{\mathrm{i}}} \mathrm{C}_{\mathrm{i}}$ & Impact & 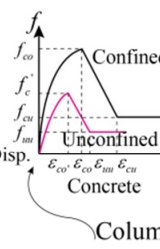 & $\underset{\text { ection }}{\stackrel{\mathrm{k}_{1}}{\mathrm{f}_{\varepsilon_{y}}}}$ \\
\hline $\begin{array}{l}\mathrm{d}_{1}=0.0465 \mathrm{~m} \\
\mathrm{~d}_{2}=0.1575 \mathrm{~m} \\
\mathrm{~F}_{1}=497 \mathrm{kN} \\
\mathrm{F}_{2}=710 \mathrm{kN}\end{array}$ & $\begin{array}{l}\mathrm{d}_{1}=0.496 \mathrm{~m} \\
\mathrm{~d}_{2}=0.174 \mathrm{~m} \\
\mathrm{~d}_{3}=0.050 \mathrm{~m} \\
\mathrm{~F}_{1}=1002 \mathrm{kN} \\
\mathrm{F}_{2}=1713 \mathrm{kN} \\
\mathrm{F}_{3}=2294 \mathrm{kN}\end{array}$ & $\begin{array}{l}\mathrm{k}_{1}=3.74 \mathrm{E} 8 \mathrm{kN} / \mathrm{m} \\
\mathrm{k}_{2}=3.74 \mathrm{E} 8 \mathrm{kN} / \mathrm{m} \\
\mathrm{k}_{3}=9.12 \mathrm{E} 8 \mathrm{kN} / \mathrm{m} \\
\mathrm{k}_{4}=8.85 \mathrm{E} 9 \mathrm{kN} / \mathrm{m} \\
\mathrm{k}_{5}=3.83 \mathrm{E} 9 \mathrm{kN} / \mathrm{m} \\
\mathrm{k}_{6}=4.52 \mathrm{E} 10 \mathrm{kN} / \mathrm{m}\end{array}$ & $\begin{array}{l}\text { Bearing at } \\
\text { abutment: } \\
\mathrm{d}_{\mathrm{y}}=0.002 \mathrm{~m} \\
\mathrm{~F}_{\mathrm{y}}=15 \mathrm{kN} \\
\text { Bearing at } \\
\text { pylon: } \\
\mathrm{d}_{\mathrm{y}}=0.002 \mathrm{~m} \\
\mathrm{~F}_{\mathrm{y}}=237 \mathrm{kN}\end{array}$ & $\begin{array}{l}\text { gap }=0.15 \mathrm{~m} \\
\mathrm{~d}_{\mathrm{y}}=0.15254 \mathrm{~m} \\
\mathrm{~d}_{\mathrm{m}}=0.1754 \mathrm{~m} \\
\mathrm{~F}_{\mathrm{y}}=562 \mathrm{kN} \\
\mathrm{F}_{\mathrm{m}}=2298 \mathrm{kN}\end{array}$ & $\begin{array}{l}\varepsilon_{c o}=0.002 \\
\varepsilon_{u u}=0.0035 \\
\varepsilon_{c u}=0.0022 \\
\varepsilon_{c c}=0.016 \\
f_{c}^{\prime}=32.4 \mathrm{MPa} \\
f_{u u}=6.48 \mathrm{MPa} \\
f_{c o}=36.5 \mathrm{MPa} \\
f_{c u}=7.3 \mathrm{MPa}\end{array}$ & $\begin{aligned} \varepsilon_{y} & =0.001675 \\
f_{y} & =335 \mathrm{MPa} \\
\mathrm{k}_{2} & =0.005 \mathrm{k}_{1}\end{aligned}$ \\
\hline
\end{tabular}

Figure 2. Analytical model of the prototype bridge. 
Table 1. Sectional properties of the bridge deck.

\begin{tabular}{ccccc}
\hline Section & Area $\left(\mathbf{m}^{2}\right)$ & $\boldsymbol{I}_{y}\left(\mathbf{m}^{\mathbf{4}}\right)$ & $\boldsymbol{I}_{z}\left(\mathbf{m}^{\mathbf{4}}\right)$ & $J\left(\mathbf{m}^{4}\right)$ \\
\hline Concrete & 11.546 & 7.512 & 352.221 & 4.287 \\
Steel & 1.850 & 0.858 & 36.282 & 0.0281 \\
\hline
\end{tabular}

\section{Thermal and Earthquake Loads}

It has been noticed that load combination does not consider the concurrent happening of temperature and earthquake loads in current bridge specifications. However, uniform temperature has significant effects on the static and dynamic responses of long-span bridges. Therefore, in order to take uniform temperature into account, thermal load is applied to the bridge before conducting the seismic analysis of the bridge. A bridge is completed in a certain period of a year, thus it will experience various temperature changes during its lifetime. These temperature changes will influence the response of the bridge. In this paper, the bridge is subjected to temperature changes $\Delta T$ of $\pm 20^{\circ} \mathrm{C}$ and $\pm 35{ }^{\circ} \mathrm{C}$, based on the construction temperature and actual temperature occurring in the bridge site.

The dynamic time history analysis is adopted for the earthquake load. In this study, three scaled earthquake records taken from the PEER ground motion database are used as shown in Table 2. The entire time history of earthquake records has been scaled to match the design response spectrum of Chinese criteria [32]. The scaling was done based on the mean squared error (MSE) of the difference between the spectral accelerations of the record and the target spectrum with period range of interest. As shown in Figure 3, three scaled records with lower MSEs in the period range from $0.2 T$ to $T(T=5.4 \mathrm{~s})$ are selected. It is noted that uniform temperature has little effect on the transverse responses of the prototype bridge. Therefore, only the longitudinal and vertical components of the selected records are input simultaneously when performing nonlinear time history analysis.

Table 2. Earthquake records used in time history analysis.

\begin{tabular}{ccccccc}
\hline No. & Record No. & Name & Time & Station & Magnitude & Scaling Factor \\
\hline 1 & 6 & Imperial Valley & 1940 & EI Centro & 6.95 & 1.07 \\
2 & 15 & Kern County & 1952 & Taft Lincoln & 7.36 & 1.73 \\
3 & 68 & San Fernando & 1971 & LA-Holly wood & 6.61 & 1.38 \\
\hline
\end{tabular}

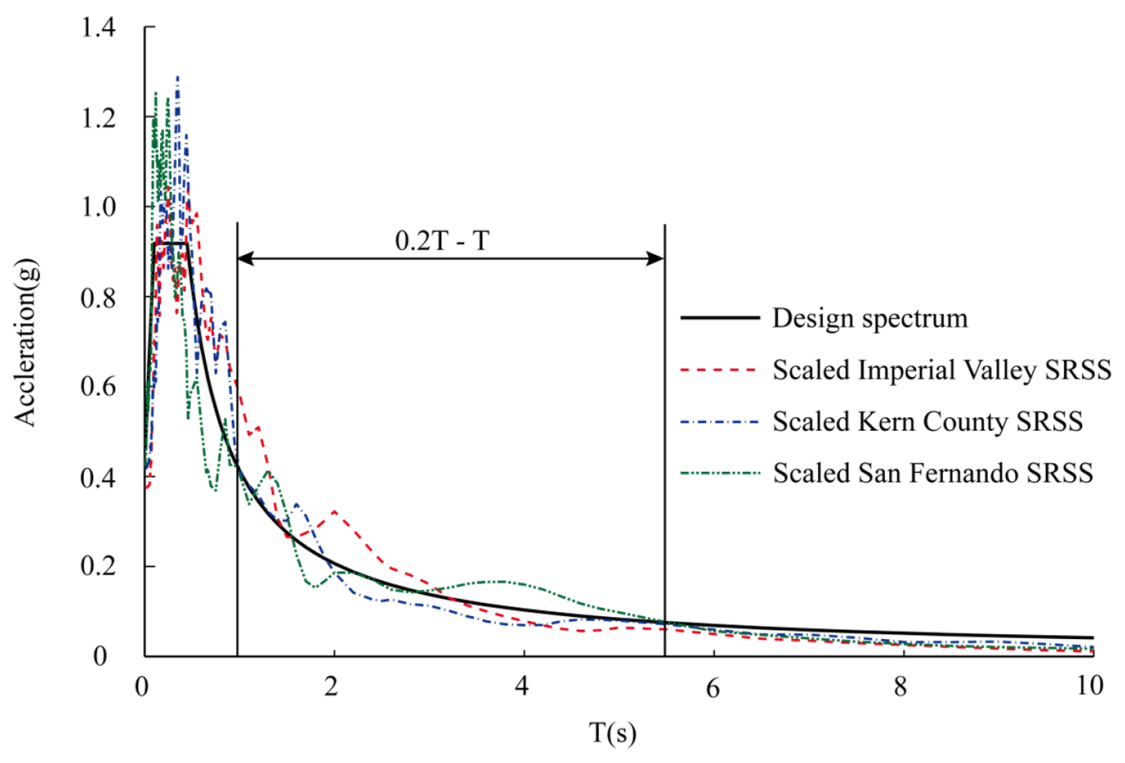

Figure 3. Scaling SRSS spectrum of the earthquake records. 


\section{Case Study and Discussion}

\subsection{Changes of Uniform Temperature Load}

The changes of temperature at the location of the bridge is hard to determine, but the intention of this paper is not investigating the complex changes of temperature. Thus, the temperature changes of $\pm 20^{\circ} \mathrm{C}$ and $\pm 35^{\circ} \mathrm{C}$ are adopted with consideration of the maximum temperature change of the bridge site. As a matter of fact, the temperature changes mentioned before may occur frequently during the lifetime of the bridge. The concurrent occurrence of the temperature and earthquake loadings should not be neglected. Otherwise, it may lead to non-conservative design.

Figure $4 \mathrm{a}, \mathrm{b}$ presents the time history of the bearing displacements at the abutment with temperature change of $\pm 20^{\circ} \mathrm{C}$ and $\pm 35^{\circ} \mathrm{C}$, respectively. It is found that the seismic displacement of the bearing will deviate from the axis due to the initial displacement caused by temperature change. This effect will increase the damage of bearings of the bridge when subjected to a strong earthquake. Figure $4 \mathrm{c}, \mathrm{d}$ shows the time history of the pounding force between the deck and abutment with different temperature changes. It is indicated that the initial gap between the deck and the abutment will decrease, attributed to the elongation of the deck with positive temperature change. Thus, the pounding at the expansion joints will frequently happen, and this increases the damage risk of the deck and abutments. As can be seen from the figure, the bending moment at the bottom of the pylon will also increase with the temperature changes.

Some peak responses of the bridge are listed in Table 3. The results show a maximum increase of $16.5 \%$ for the compressive force of the deck and an increase of $11.7 \%$ for the tensile force of the deck. This increase is mainly attributed to the partially longitudinal restraints provided by the bearings between the deck and the pylons. The axial deformation of the deck due to temperature changes will be restrained by the bearings, and this will significantly affect the axial force of the deck.

In Table 3, bearing displacement at the abutment will sharply increase with temperature changes and the same phenomenon will be seen about pounding force. These can be explained as follows: the gap between the deck and the abutments will be narrowed due to positive temperature loading, which will not only increase the displacement of the bearing, but also increase the probability of pounding.

Table 3. Seismic responses of the bridge with varying temperature.

\begin{tabular}{|c|c|c|c|c|c|c|}
\hline Responses & $\begin{array}{c}\text { Earthquake } \\
\text { No. }\end{array}$ & $\Delta T=0\left({ }^{\circ} \mathrm{C}\right)$ & $\Delta T= \pm 20\left({ }^{\circ} \mathrm{C}\right)$ & $\begin{array}{c}\text { Increase } \\
(\%)\end{array}$ & $\Delta T= \pm 35\left({ }^{\circ} \mathrm{C}\right)$ & $\begin{array}{c}\text { Increase } \\
(\%)\end{array}$ \\
\hline \multirow{3}{*}{$\begin{array}{l}F_{x}(\text { comp. }) \text { in } \\
\operatorname{deck}(\mathrm{kN})\end{array}$} & 1 & 58,888 & 59,351 & 0.79 & 60,877 & 3.38 \\
\hline & 2 & 63,686 & 64,329 & 1.01 & 66,402 & 4.26 \\
\hline & 3 & 62,965 & 69,969 & 11.12 & 73,354 & 16.50 \\
\hline \multirow{3}{*}{$\begin{array}{l}F_{x}(\text { tensile }) \text { in } \\
\operatorname{deck}(\mathrm{kN})\end{array}$} & 1 & 26,520 & 26,617 & 0.37 & 26,982 & 1.74 \\
\hline & 2 & 42,662 & 42,969 & 0.72 & 43,353 & 1.62 \\
\hline & 3 & 27,409 & 27,494 & 0.31 & 30,616 & 11.70 \\
\hline \multirow{3}{*}{$\begin{array}{l}\text { Pounding force } \\
\qquad(\mathrm{kN})\end{array}$} & 1 & 2501 & 3666 & 46.58 & 6155 & 146.10 \\
\hline & 2 & 11,892 & 17,951 & 50.95 & 15,846 & 33.25 \\
\hline & 3 & 21,196 & 26,112 & 23.19 & 27,909 & 31.67 \\
\hline \multirow{3}{*}{$\begin{array}{l}\text { Bearing disp. at } \\
\text { abutment (m) }\end{array}$} & 1 & 0.11 & 0.19 & 72.73 & 0.25 & 127.27 \\
\hline & 2 & 0.34 & 0.47 & 38.24 & 0.42 & 23.53 \\
\hline & 3 & 0.55 & 0.68 & 23.64 & 0.76 & 38.18 \\
\hline \multirow{3}{*}{$\begin{array}{c}M_{y} \text { at pylon } \\
\text { bottom }(\mathrm{kN} \cdot \mathrm{m})\end{array}$} & 1 & $1,176,896$ & $1,224,878$ & 4.08 & $1,347,783$ & 14.52 \\
\hline & 2 & $1,929,557$ & $2,000,932$ & 3.70 & $2,045,541$ & 6.01 \\
\hline & 3 & $1,531,194$ & $1,732,721$ & 13.16 & $1,845,110$ & 20.50 \\
\hline
\end{tabular}




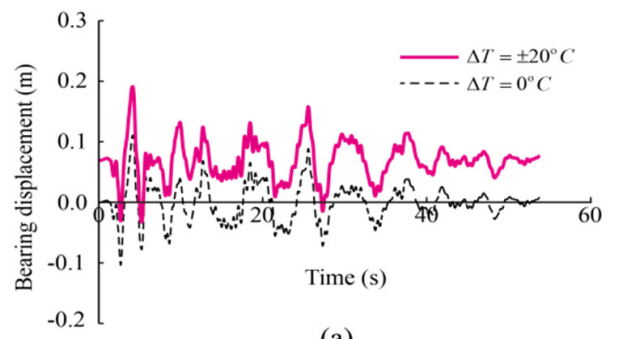

(a)

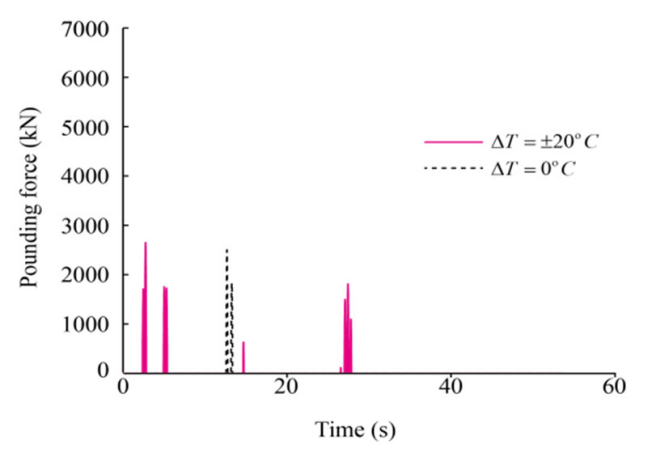

(c)

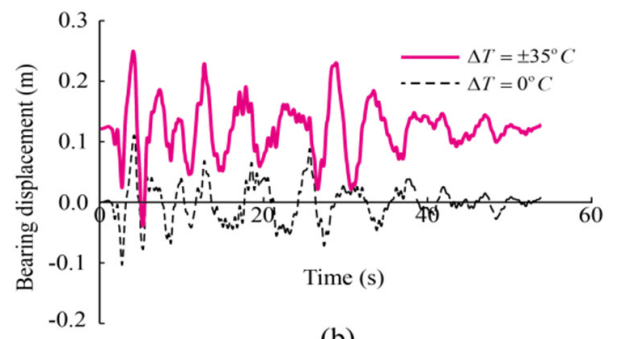

(b)

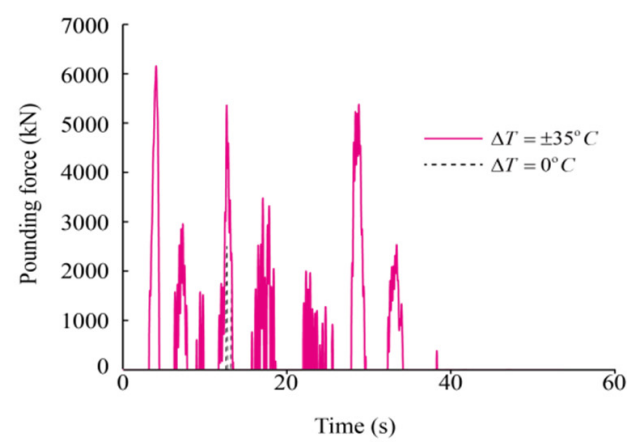

(d)

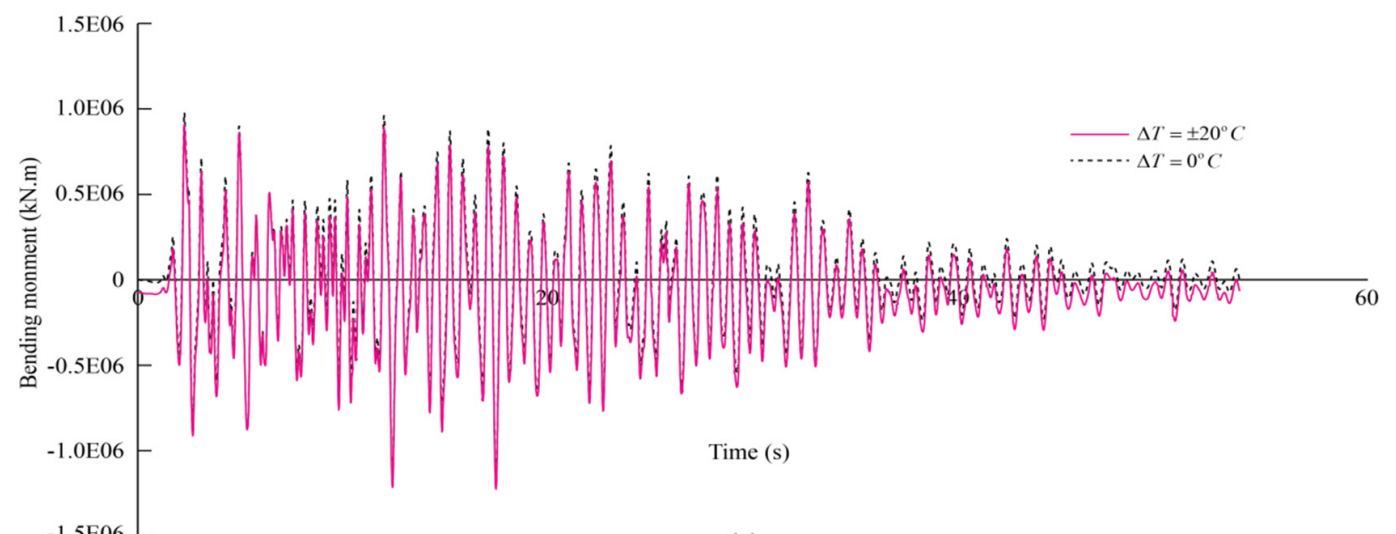

(e)

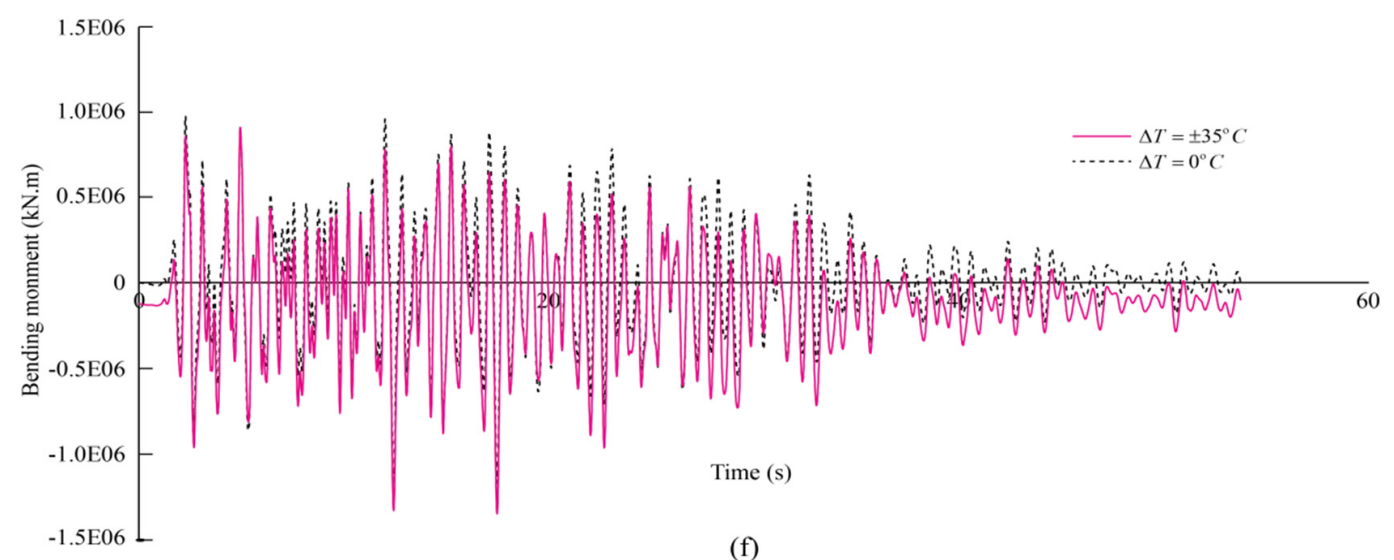

Figure 4. Time history of the bridge components with varying temperature; $(\mathbf{a}, \mathbf{b})$ displacement of the bearing at abutment with changing temperatures of $\pm 20^{\circ} \mathrm{C}$ and $\pm 35^{\circ} \mathrm{C}$, respectively; (c,d) pounding force between the girder and abutment with changing temperatures of $\pm 20^{\circ} \mathrm{C}$ and $\pm 35^{\circ} \mathrm{C}$ respectively; $(\mathbf{e}, \mathbf{f})$ Bending moment at the bottom of the pylon with changing temperatures of $\pm 20{ }^{\circ} \mathrm{C}$ and $\pm 35^{\circ} \mathrm{C}$, respectively. 
It also can be seen from the table that the bending moment at the pylon bottom will increase with temperature load. This is mainly because of the initial shear force of the bearings caused by temperature being transformed to the pylons before seismic excitation. Cable forces are listed in Table 4, it is found that cable forces slightly increased with temperature changes. Lepidi and Gattulli [18] studied the static and dynamic responses of stay cables with thermal effects, and found that the thermal effects influence the frequencies of stay cables. The results of cable forces here may be attributed to the OECS model's inability to take the local vibration of stay cables into consideration, and the deck and pylon are connected by moveable bearings that can relieve the thermal effects.

Table 4. Earthquake records used in time history analysis.

\begin{tabular}{cccccc}
\hline Cable No. & $\mathbf{0}\left({ }^{\circ} \mathbf{C}\right)$ & $\mathbf{\pm 2 0}\left({ }^{\circ} \mathbf{C}\right)$ & Increase $(\%)$ & $\pm \mathbf{3 5}\left({ }^{\circ} \mathbf{C}\right)$ & Increase $(\mathbf{\%})$ \\
\hline 1 & 2827 & 2863 & 1.273 & 2872 & 1.592 \\
18 & 2475 & 2485 & 0.404 & 2496 & 0.848 \\
\hline
\end{tabular}

\subsection{Deck to Pylon Connections}

The connection form between the deck and the pylons is an important issue when designing cable-stayed bridges, which determines the path of the forces transformed to the substructure. It is noted that the forces of the superstructure can be transmitted either from cables or from the connection between the deck and the pylons. Three types of connections, in Figure 5, are considered in current research: Connection 1 (deck to pylon is connected by movable bearings), Connection 2 (deck to pylon is not connected), and Connection 3 (deck to pylon is restrained in longitudinal direction). Although Connection 3 is not adopted in the real structure, it is used here to illustrate the effects of different connections on the seismic responses of the bridge with uniform temperature. The seismic responses of the bridge for different deck to pylon connections with temperature changes of $\pm 0{ }^{\circ} \mathrm{C}$ and $\pm 35^{\circ} \mathrm{C}$ are listed in Table 5. The results show that the seismic responses of the bridge with and without temperature changes are notably different for various connections. Notably, the bending moment at the pylon bottom in Connection 3 is much larger than that in Connection 1 and Connection 2. This can be attributed to the strong restraints between the deck and the pylons in the longitudinal direction.
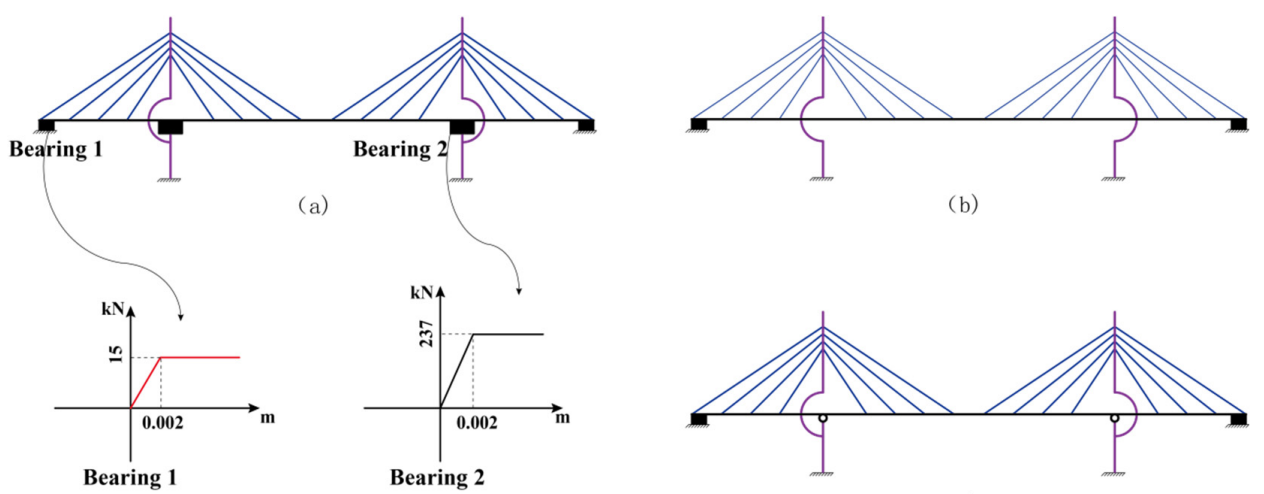

(b)

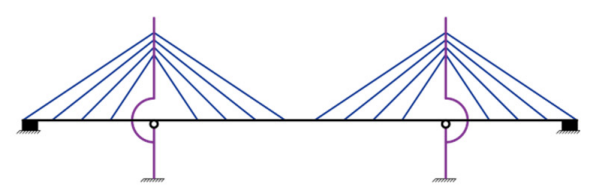

(c)

Figure 5. Schematic models of different deck to pylon connections; (a) Connection 1-connected by bearings in longitudinal direction; (b) Connection 2-not restrained in longitudinal direction; (c) Connection 3-restrained in longitudinal direction.

The ratios between the internal forces and displacement of Connection 1, Connection 2, and Connection 3 with temperature change of $\pm 35^{\circ} \mathrm{C}$ and with temperature of $\pm 0{ }^{\circ} \mathrm{C}$ are listed in Figure 6 . The result indicates that Connection 2 does not have a better performance compared with Connection 1 because of the different paths of force transmission. In Connection 1, the forces of the superstructure 
are transmitted both from cables and bearings, whereas, in Connection 2, the forces are transmitted mainly from cables. Therefore, the distances between the shear forces transmitted to the pylon and pylon bottom are significantly different for Connection 1 and Connection 2. Meanwhile, most of the responses of the bridge with different connections are significantly affected by the temperature loading. For example, the bending moments at the pylon bottom of the bridge with different connections are increased by $15 \%, 17 \%$ and $64 \%$ respectively with the temperature change of $\pm 35^{\circ} \mathrm{C}$. Pylons, as a critical component of cable-stayed bridges, are vulnerable to strong earthquake. Therefore, the increase of the bending moment demand on the pylon due to temperature loading will further increase the risk of the bridge under strong earthquake.

Table 5. Seismic responses of the bridge for different deck to pylon connections with temperature changes of $\pm 0{ }^{\circ} \mathrm{C}$ and $\pm 35^{\circ} \mathrm{C}$, respectively.

\begin{tabular}{|c|c|c|c|c|c|c|}
\hline \multirow{2}{*}{ Responses } & \multicolumn{2}{|c|}{ Connection 1} & \multicolumn{2}{|c|}{ Connection 2} & \multicolumn{2}{|c|}{ Connection 3} \\
\hline & $\Delta T=0\left({ }^{\circ} \mathrm{C}\right)$ & $\Delta T= \pm 35\left({ }^{\circ} \mathrm{C}\right)$ & $\Delta T=0\left({ }^{\circ} \mathrm{C}\right)$ & $\Delta T= \pm 35\left({ }^{\circ} \mathrm{C}\right)$ & $\Delta T=0\left({ }^{\circ} \mathrm{C}\right)$ & $\Delta T= \pm 35\left({ }^{\circ} \mathrm{C}\right)$ \\
\hline$P_{\text {comp. }}{ }^{1}(\mathrm{kN})$ & 58,888 & 60,877 & 60,213 & 63,193 & 77,877 & 79,850 \\
\hline$P_{\text {tensile }}{ }^{2}(\mathrm{kN})$ & 25,193 & 26,982 & 28,937 & 29,075 & 21,747 & 56,249 \\
\hline$P_{\text {pound }}{ }^{3}(\mathrm{kN})$ & 2501 & 6156 & 2621 & 6266 & 2600 & 6625 \\
\hline$\Delta_{\text {bearing }}^{4}(\mathrm{~m})$ & 0.11 & 0.25 & 0.11 & 0.25 & 0.12 & 0.24 \\
\hline$M_{\text {pylon }}{ }^{5}(\mathrm{kN} \cdot \mathrm{m})$ & $1,176,896$ & $1,347,783$ & $1,295,675$ & $1,513,304$ & $2,390,025$ & $3,918,211$ \\
\hline$\Delta_{\text {pylon }}{ }^{6}(\mathrm{~m})$ & 0.16 & 0.24 & 0.16 & 0.26 & 0.24 & 0.34 \\
\hline$\Delta_{\text {passive }}{ }^{7}(\mathrm{~m})$ & 0.02 & 0.02 & 0.02 & 0.02 & 0.02 & 0.04 \\
\hline$P_{\text {passive }}^{8}(\mathrm{kN})$ & 7709 & 7169 & 7899 & 8866 & 7231 & 11,232 \\
\hline
\end{tabular}

${ }^{1}$ Compressive axial force in the deck; ${ }^{2}$ Tensile axial force in the deck; ${ }^{3}$ Pounding force in the abutment;

${ }^{4}$ Bearing displacement at the abutment; ${ }^{5}$ Bending moment at the pylon bottom; ${ }^{6}$ Joint displacement at the pylon top; ${ }^{7}$ Passive soil displacement at the abutment; ${ }^{8}$ Passive soil force at the abutment.

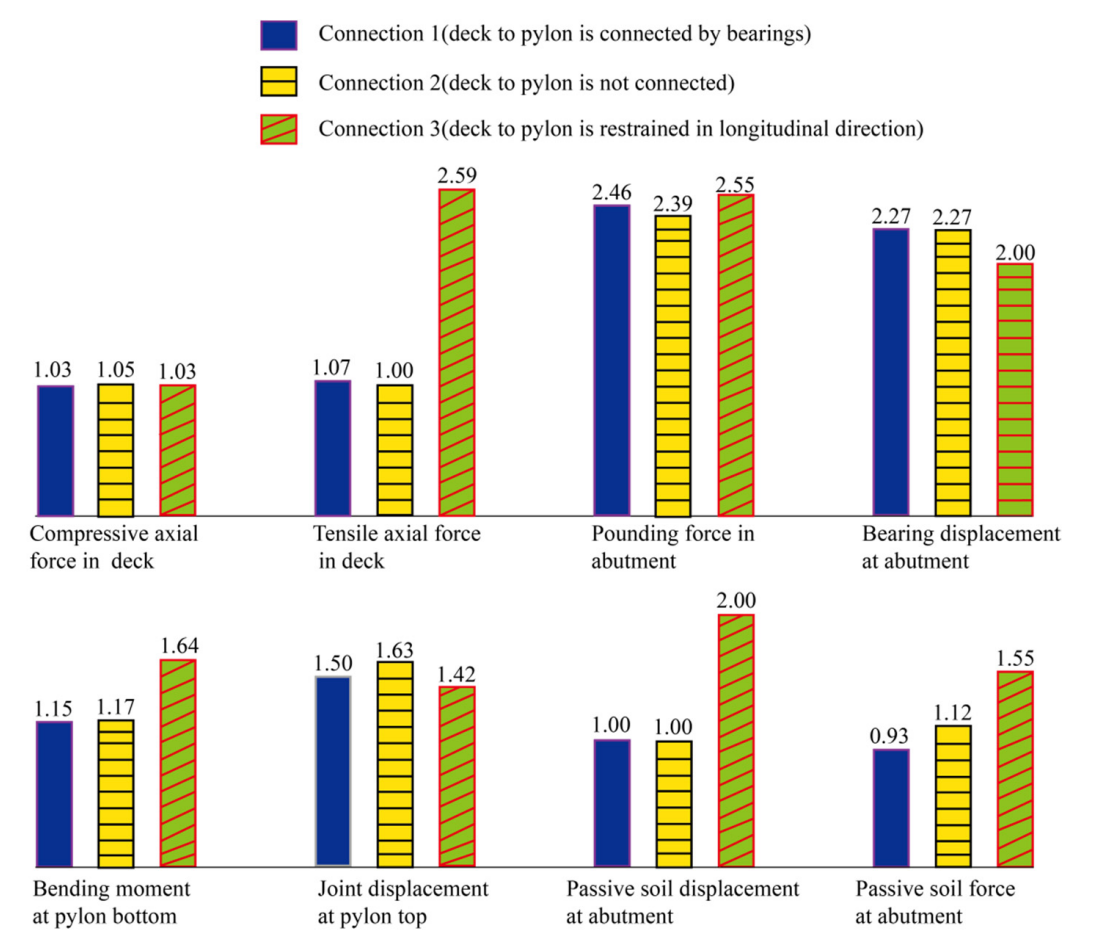

Figure 6. The ratios of the responses of the bridge with temperature change of $\pm 35{ }^{\circ} \mathrm{C}$ to their counterparts with changing temperature of $\pm 0{ }^{\circ} \mathrm{C}$ for different deck/pylon connections.

The type of the deck to pylon connection has a significant effect on the responses of the bridge during a strong earthquake with consideration of temperature loading. Generally speaking, Connection 3 is not 
suitable for the connection of a cable-stayed bridge since the responses of the bridge will be sharply increased under either earthquake loading or temperature loading. Thus, Connection 1 or Connection 2 can be considered as the candidate of both seismic excitation and temperature loadings.

\section{Conclusions}

The main purpose of this article is to analyze the effects of uniform temperature on the seismic responses of a cable-stayed bridge. A three-dimensional finite element model was constructed for nonlinear dynamic time history analysis of the cable-stayed bridge. The nonlinear behaviors, such as geometry nonlinear, material nonlinear, and $p-\Delta$ effect, were considered in the finite element model. A case study was performed to investigate the effects of the temperature changes on the seismic responses of the bridge. Based on the numerical research, the main results are as follows:

(1) The seismic responses of the bridge are significantly increased with the consideration of temperature load. They almost linearly increase with the temperature changes of $\pm 20^{\circ} \mathrm{C}$ and $\pm 35^{\circ} \mathrm{C}$. The result indicates that the effects of temperature load on the seismic responses of the bridge should be considered during the design phase of cable-stayed bridges.

(2) The connections between the deck and the pylons have significant effects on the seismic responses of the bridge with and without temperature load. It is also found that the responses of the critical components in Connection 3 (deck to pylon is restrained in longitudinal direction) are much larger than those in other connections. Therefore, Connection 1 (deck to pylon is connected by bearing) or Connection 2 (deck to pylon is not connected) can be selected in practice with the consideration of both earthquake and temperature loads.

This paper only investigates the seismic responses of a prototype bridge under thermal effects with a small number of numerical analysis. More analysis will be conducted to generalize the effects of uniform temperature on the seismic responses of bridges in the future.

Acknowledgments: The author(s) disclosed receipt of the following financial support for the research, authorship, and/or publication of this article: This study was supported by State Key Laboratory of Disaster Reduction in Civil Engineering under Grant No. SLDRCE14-B-14; the National Natural Science Foundation of China under Grant Nos. 51478339, 51278376, 51608161, and 91315301; the National Key Technology Research and Development of the Ministry of Science and Technology of China under Grant No. 2015BAK17B04; and the Science Technology Plan of JiangXi Province under Grant No. 20151BBG70064. All support is gratefully acknowledged.

Author Contributions: Wancheng Yuan mainly proposed the problem that the effects of the uniform temperature on the seismic responses should be considered during design phases of cable-stayed bridges. Junjun Guo, Jian Zhong, and Xinzhi Dang established the finite element model of the prototype bridge. All of the authors did the simulation analysis, and discussed the results, as well as contributed to the paper writing work.

Conflicts of Interest: The authors declare no conflict of interest.

\section{References}

1. Wang, J.; Zou, X.; Yan, X.; Li, S. Integrated analysis model for the seismic responses of cable-stayed bridges near active faults. J. Earthq. Tsunami 2015, 9. [CrossRef]

2. Shrestha, B. Seismic response of long span cable-stayed bridge to near-fault vertical ground motions. KSCE J. Civ. Eng. 2014, 19, 180-187. [CrossRef]

3. Ismail, M.; Casas, J.R.; Rodellar, J. Near-fault isolation of cable-stayed bridges using RNC isolator. Eng. Struct. 2013, 56, 327-342. [CrossRef]

4. Ismail, M.; Casas, J.R. Novel isolation device for protection of cable-stayed bridges against near-fault earthquakes. J. Bridge Eng. 2013, 19, A4013002. [CrossRef]

5. Wesolowsky, M.J.; Wilson, J.C. Seismic isolation of cable-stayed bridges for near-field ground motions. Earthq. Eng. Struct. Dyn. 2003, 32, 2107-2126. [CrossRef]

6. Atmaca, B.; Yurdakul, M.; Ateş, Ş. Nonlinear dynamic analysis of base isolated cable-stayed bridge under earthquake excitations. Soil Dyn. Earthq. Eng. 2014, 66, 314-318. [CrossRef]

7. Seed, F.K.A.; Ahmed, H.H.; Raheem, S.E.A.; Shafy, Y.A. Dynamic non-linear behaviour of cable stayed bridges under seismic loadings. Life Sci. J. 2013, 4, 3725-3741. 
8. Raheem, S.E.A.; Hayashikawa, T. Soil-structure interaction modeling effects on seismic response of cable-stayed bridge tower. Int. J. Adv. Struct. Eng. 2013, 5, 1-17. [CrossRef]

9. De, S.; Wojtkiewicz, S.F.; Johnson, E.A. Efficient optimal design and design-under-uncertainty of passive control devices with application to a cable-stayed bridge. Struct. Control Health Monit. 2016. [CrossRef]

10. Shi, X.; Zhu, S.; Li, J.Y.; Spencer, B.F., Jr. Dynamic behavior of stay cables with passive negative stiffness dampers. Smart Mater. Struct. 2016, 25, 1-14. [CrossRef]

11. Zhu, J.; Zhang, W.; Zheng, K.F.; Li, H.G. Seismic design of a long-span cable-stayed bridge with fluid viscous dampers. Pract. Period. Struct. Des. Constr. 2015, 21. [CrossRef]

12. Martínez-Rodrigo, M.D.; Filiatrault, A. A case study on the application of passive control and seismic isolation techniques to cable-stayed bridges: A comparative investigation through non-linear dynamic analyses. Eng. Struct. 2015, 99, 232-252. [CrossRef]

13. Sharabash, A.M.; Andrawes, B.O. Application of shape memory alloy dampers in the seismic control of cable-stayed bridges. Eng. Struct. 2009, 31, 607-616. [CrossRef]

14. Domaneschi, M.; Martinelli, L. Extending the benchmark cable-stayed bridge for transverse response under seismic loading. J. Bridge Eng. 2014, 19, 165-184. [CrossRef]

15. Zhou, G.D.; Yi, T.H. A Summary review of correlations between temperatures and vibration properties of long-span bridges. Math. Probl. Eng. 2014, 2014, 1-19. [CrossRef]

16. Ding, Y.L.; Li, A.Q. Temperature-induced variations of measured modal frequencies of steel box girder for a long-span suspension bridge. Int. J. Steel Struct. 2011, 11, 145-155. [CrossRef]

17. Cao, Y.; Yim, J.; Zhao, Y.; Wang, M.L. Temperature effects on cable stayed bridge using health monitoring system: A case study. Struct. Health Monit. 2010, 10, 523-537.

18. Arena, A.; Pacitti, A.; Lacarbonara, W. Nonlinear response of elastic cables with flexural-torsional stiffness. Int. J. Solids Struct. 2015, 87, 267-277. [CrossRef]

19. Lepidi, M.; Gattulli, V. Static and dynamic response of elastic suspended cables with thermal effects. Int. J. Solids Struct. 2012, 49, 1103-1116. [CrossRef]

20. Qiu, W.L.; Zhe, Z. Research on combination of seismic and temperature action effects of bridge structures. Dalian Ligong Daxue Xue Bao J. Dalian Univ. Technol. 2011, 51, 540-544.

21. Maleki, S.; Maghsoudi-Barmi, A. Effects of concurrent earthquake and temperature loadings on cable-stayed bridges. Int. J. Struct. Stab. Dyn. 2015, 16, 1550020. [CrossRef]

22. Zhong, J.; Pang, Y.; Jeon, J.S.; Desroches, R.; Yuan, W. Seismic fragility assessment of long-span cable-stayed bridges in China. Adv. Struct. Eng. 2016. [CrossRef]

23. Mckenna, F.; Scott, M.H.; Fenves, G.L. Nonlinear finite-element analysis software architecture using object composition. J. Comput. Civ. Eng. 2010, 24, 95-107. [CrossRef]

24. Wilson, J.C.; Wayne, G. Modelling of cable-stayed bridge for dynamic analysis. Earthq. Eng. Struct. Dyn. 1991, 20, 707-721. [CrossRef]

25. Elsa, C.; Alvaro, C.; Vincenzo, G.; Marco, L. Cable-deck dynamic interactions at the International Guadiana Bridge: On-site measurements and finite element modelling. Struct. Control Health Monit. 2008, 15, 237-264.

26. Ernst, J.H. Der E-Modul von Seilen unter berucksichtigung des Durchhanges. Der Bauing. 1965, 40, 52-55.

27. Caetano, E.; Cunha, A.; Taylor, C.A. Investigation of Dynamic Cable-deck Interaction in a Physical Model of a Cable-stayed Bridge. Part I: Modal Analysis. Earthq. Eng. Struct. Dyn. 2000, 29, 481-498. [CrossRef]

28. Caetano, E.; Cunha, A.; Taylor, C.A. Investigation of dynamic cable-deck interaction in a physical model of a cable-stayed bridge. Part II: Seismic response. Earthq. Eng. Struct. Dyn. 2000, 29, 499-521. [CrossRef]

29. Gattulli, V.; Lepidi, M. Localization and veering in the dynamics of cable-stayed bridges. Comput. Struct. 2007, 85, 1661-1678. [CrossRef]

30. Yashinsky, M.; Ostrom, T. Caltrans new seismic design criteria for bridges. Earthq. Spectr. 2000, 1, 285-307. [CrossRef]

31. Desroches, R.; Muthukumar, S. Effect of Pounding and restrainers on seismic response of multiple-frame bridges. J. Struct. Eng. 2002, 128, 860-869. [CrossRef]

32. Ministry of Transport of the People's Republic of China (MOT). Guidelines for Seismic Design of Highway Bridges; MOT: Beijing, China, 2008.

(C) 2016 by the authors; licensee MDPI, Basel, Switzerland. This article is an open access article distributed under the terms and conditions of the Creative Commons Attribution (CC-BY) license (http://creativecommons.org/licenses/by/4.0/). 